\title{
HAMILTON AND THE LAW
}





\title{
HAMILTON AND THE LAW
}

\section{Reading Today's Most Contentious Legal Issues through the Hit Musical}

\author{
Edited by Lisa A. Tucker
}


Dedication sources: Lin-Manuel Miranda, "Dear Theodosia," Hamilton: An American Musical (Atlantic Records 2015); Stephen Sondheim, "Finishing the Hat," Sunday in the Park with George (RCA 1984); Miranda, "Best of Wives and Best of Women," Hamilton; Miranda, "Satisfied," Hamilton.

\section{Copyright (C) 2020 by Cornell University}

\section{Chapter 10 copyright () 2020 by Christina Mulligan}

All rights reserved. Except for brief quotations in a review, this book, or parts thereof, must not be reproduced in any form without permission in writing from the publisher. For information, address Cornell University Press, Sage House, 512 East State Street, Ithaca, New York 14850. Visit our website at cornellpress.cornell.edu.

First published 2020 by Cornell University Press

Printed in the United States of America

Library of Congress Cataloging-in-Publication Data

Names: Tucker, Lisa A., editor.

Title: Hamilton and the law : reading today's most contentious legal issues through the hit musical / edited by Lisa A. Tucker.

Description: Ithaca [New York] : Cornell University Press, 2020. I Includes bibliographical references and index.

Identifiers: LCCN 2020007218 (print) I LCCN 2020007219 (ebook) | ISBN 9781501752216 (hardcover) I ISBN 9781501753381 (paperback) | ISBN 9781501752223 (ebook) I ISBN 9781501752230 (pdf)

Subjects: LCSH: Law-Political aspects-United States. I Hamilton, Alexander, 1757-1804_Influence. I Miranda, Lin-Manuel, 1980Hamilton-Influence. I Musical theater-Political aspectsUnited States-History-21st century. I History in popular cultureUnited States-History-21st century.

Classification: LCC KF211. H357 2020 (print) I LCC KF211 (ebook) | DDC 349.73-dc23

LC record available at https://lccn.loc.gov/2020007218

LC ebook record available at https://lccn.loc.gov/2020007219 
For Zoe and Abby:

Pride is not the word I'm looking for. There is so much more inside me.

Look, I made a hat!

For Adam:

Best of men, best of husbands.

So this is what it's like to match wits! 
